\title{
Taman Rekreasi Pantai Pasarbanggi Dengan Pendekatan ARsitekTUR EKologis Di KabUPATEN REMBANG
}

\author{
Fitri Sari Purnama Arum, Hadi Setyawan, Marsudi. \\ Program Studi Arsitektur \\ Universitas Sebelas Maret Surakarta \\ Email : tetha.andromeda09@gmail.com
}

\begin{abstract}
Planning and designing Beach Recreation Park Pasarbanggi background by public interest Rembang at recreation park compared to other types of recreation, a need for new tourist destinations in Rembang, potential Pasarbanggi Beach, tourist destination development is the development of a tourist attraction Mangrove Forest Pasarbanggi, and reduce the impact of environmental damage Pasarbanggi Beach. The issue of how to apply the concept of ecological design with a focus on the use of ecological materials, energy efficiency, and waste management in buildings and Recreation Park area in an effort to minimize its environmental impact. The objective of this scheme is to acquire the building design and Recreation Park area as a place of education and leisure by applying the concept of Ecological Architecture. Architectural design method with Ecological Architecture approach is a method to be used and applied to the design of the building and neighborhood Taman Rekreasi Pasarbanggi. Then the results are designs Recreation Park with Ecological Architecture approach that is applied to the use of ecological materials such as exposed brick walls, ceiling container scrap wood and exposed concrete floors; energy efficiency in buildings and the area in the form of the use of sky light in the roof of the building, multiply the number of openings with a transparent glass material, the use of a secondary skin to reduce the sunlight; and the management of waste in the form of management and processing of organic waste into compost, and inorganic waste processing to produce handicrafts.
\end{abstract}

Keywords: Ecological Architecture, Energy Efficiency, Recreation Park, Waste Management.

\section{PENDAHULUAN}

Dalam kehidupan sehari-hari, manusia membutuhkan keseimbangan. Salah satunya dalam hal pemenuhan kebutuhan rohani. Kebutuhan rohani dapat dipenuhi dengan berwisata. Berwisata dapat menjadi sarana pelepas stress dan penat bagi masyarakat yang kehidupan sehari-hari penuh dengan tekanan pekerjaan. Salah satu jenis wisata tersebut adalah wisata buatan.

Menurut data dari Dinas Kebudayaan Pariwisata Pemuda dan Olah Raga Kabupaten Rembang, jumlah kunjungan Objek Wisata Tahun 2009-2013 berturut-turut pada Taman Rekreasi Pantai Kartini yaitu 213.049 pengunjung, 236.795 pengunjung, 391.341 pengunjung, 1.182.313 pengunjung, 276.249 pengunjung. Jumlah tersebut lebih tinggi dibanding jumlah kunjungan wisata pada objek wisata lainnya di Kabupaten Rembang, sehingga dari data tersebut dapat disimpulkan bahwa taman rekreasi lebih diminati oleh masyarakat Rembang pada umumnya.

Jumlah pengunjung wisata di Rembang mengalami fluktuasi dan menurun drastis pada tahun 2013, sehingga perlu adanya pengembangan destinasi wisata untuk kembali mendongkrak minat masyarakat untuk berwisata.

Pasarbanggi merupakan salah satu desa dengan potensi hutan mangrove. Menurut Dinas Kelautan dan Perikanan Kabupaten Rembang dalam Profil KP 2013, di Kecamatan Rembang, komunitas mangrove dapat dijumpai di Desa Kabongan Lor, Tireman dan Pasar Banggi dengan luas sekitar $15 \mathrm{Ha}$, dengan panjang hamparan $3 \mathrm{~km}$ dan rata-rata ketebalan $50 \mathrm{~m}$. Pantai Pasarbanggi sendiri merupakan salah satu wisata alam di Kabupaten Rembang. Selain itu, kawasan Pantai Pasarbanggi terdapat tambak garam dengan teknik pembuatan garam yang masih tradisional, mulai dari cara pengambilan air 
laut dengan memanfaatkan energi angin, pengerasan lahan penampungan air laut yang dijadikan garam, sampai proses pengangkutan garam menuju ke gudang-gudang penyimpanan.

Rencana Kerja Pemerintah Daerah (RKPD) Kabupaten Rembang tahun 2015, salah satu program pengembangan destinasi pariwisata yaitu pengembangan daya tarik wisata hutan mangrove. Salah satu cara untuk mengembangkan wisata hutan mangrove adalah dengan merencanakan dan merancang suatu objek wisata baru yang fungsinya dapat mendukung wisata hutan mangrove. Objek wisata yang direncanakan adalah taman rekreasi dengan fasilitas rekreasi berupa bermacam atraksi wisata, baik yang telah ada sebelumnya maupun atraksi wisata yang baru dibuat.

Pendekatan Arsitektur Ekologis pada Taman Rekreasi Pantai Pasarbanggi dikarenakan pantai merupakan suatu kawasan alam dengan ekosistem yang sangat sensitif dan mudah mengalami kerusakan jika salah dalam hal perencanaan dan pengelolaan pariwisata. Ketika suatu pembangunan kawasan wisata tidak menerapkan prinsipprinsip ekologis, maka dikhawatirkan akan terjadi kerusakan alam yang tentunya berdampak pada keberlangsungan kegiatan wisata pada daerah tersebut, sehingga dalam hal perencanaan dan perancangan taman rekreasi yaitu dengan menerapkan prinsipprinsip Arsitektur Ekologis.

Banyak orang berpendapat bahwa industri pariwisata dengan sendirinya akan dilaksanakan dengan cara yang akrab lingkungan terhadap alam. Pendapat ini didasari pengendalian bahwa daya tarik wisata, antara lain, menyangkut lingkungan yang bersih dan sehat sebagai persyaratan utama yang hampir menjadi kebutuhan yang mutlak sifatnya. (Prof. Dr. R.E. Soeriaatmadja, 1996). Kabupaten Rembang yang memiliki garis pantai sepanjang 65 kilometer tentu tidak terlepas dari masalah abrasi. Rata-rata hilangnya daratan per tahun mencapai 5-30 meter dari bibir pantai.

Kabupaten Rembang merupakan suatu kabupaten di pesisir Jawa Tengah dengan masyarakatnya yang jauh dari budaya ekologis, terutama masalah akan sampah dan pengolahannya serta dilakukan pengurukan pantai yang bersifat illegal, sehingga dapat disaksikan betapa ekosistem di sekitar pesisir pantai di Kabupaten Rembang sudah begitu kritis dan diambang kerusakan.

\section{METODE}

Berdasarkan konsep perencanaan dan perancangan, Taman Rekreasi Pantai Pasarbanggi yang direncanakan menerapkan konsep ekologis yang fokus pada beberapa aspek.

Aspek penghawaan dan pencahayaan alami untuk efisiensi penggunaan energi pada bangunan, memperbanyak jumlah bukaan dengan penempatan yang tepat sesuai arah datangnya angin, penempatan vegetasi maupun secondary skin guna mereduksi sinar matahari, penempatan sky light pada atap bangunan untuk penerangan pada ruang dalam bangunan yang luas, penerapan bukaan dengan material transparan seperti kaca.

Aspek berikutnya yaitu penggunaan material ekologis. Penggunaan material ekologis yang diterapkan pada kawasan taman rekreasi yang direncanakan antara lain, penggunaan material bekas pakai, seperti keramik bekas pakai sebagai penutup dinding dan lantai pada area toilet, penggunaan kayu jati belanda bekas peti kemas sebagai elemen interior plafond, dan penggunaan kayu bekas pakai untuk kebutuhan partisi dan lain-lain, efisiensi penggunaan material, seperti penggunaan dinding bata merah ekspos dengan finishing cat dinding atau tanpa finishing, dan lantai dengan material beton ekspos.

Aspek terakhir yaitu manajemen dan pengelolaan limbah. Pengelolaan dan pengolahan sampah organik sebagai pupuk organik. Pengolahan sampah organik dilakukan oleh pengunjung sebagai wujud wisata edukasi, pengolahan dan pemanfaatan sampah anorganik sebagai barang yang berguna bagi kehidupan sehari-hari, seperti tas belanja dari plastik bekas bungkus makanan, pot dari botol bekas, dan lain-lain. Pengolahan sampah anorganik dilakukan oleh pengunjung sebagai wujud wisata edukasi, pengolahan dan pengelolaan air kotor, baik yang berasal dari toilet, air bekas cuci tangan, dan air bekas wudhu untuk menyiram tanaman.

\section{ANALISIS}


1. Tujuan : Pengelompokan fasilitas berdasarkan jenis kegiatan pengguna yang direncanakan pada Taman Rekreasi Pantai Pasarbanggi

2. Dasar Pertimbangan : Berdasarkan analisis pelaku kegiatan, kelompok kegiatan dan pola kegiatan pelaku.

Tabel 1.Kebutuhan Ruang

\begin{tabular}{|c|c|c|}
\hline PELAKU & KEGIATAN & PERUANGAN \\
\hline \multirow{15}{*}{$\begin{array}{l}\text { Pengun- } \\
\text { jung }\end{array}$} & Datang & Hall penerima \\
\hline & Parkir & $\begin{array}{l}\text { Parkir } \\
\text { pengunjung }\end{array}$ \\
\hline & $\begin{array}{l}\text { Membeli } \\
\text { tiket }\end{array}$ & Loket tiket \\
\hline & $\begin{array}{l}\text { Mencari } \\
\text { informasi }\end{array}$ & $\begin{array}{l}\text { Ruang } \\
\text { informasi }\end{array}$ \\
\hline & Metabolisme & Toilet \\
\hline & $\begin{array}{l}\text { Edukasi } \\
\text { mengenai } \\
\text { kompos }\end{array}$ & $\begin{array}{l}\text { Rumah } \\
\text { pengolahan } \\
\text { limbah }\end{array}$ \\
\hline & $\begin{array}{l}\text { Edukasi } \\
\text { mengenai } \\
\text { mangrove }\end{array}$ & $\begin{array}{l}\text { Rumah } \\
\text { mangrove }\end{array}$ \\
\hline & $\begin{array}{l}\text { Edukasi } \\
\text { mengenai } \\
\text { garam }\end{array}$ & Rumah garam \\
\hline & $\begin{array}{l}\text { Edukasi } \\
\text { mengenai } \\
\text { bambu }\end{array}$ & Rumah bambu \\
\hline & $\begin{array}{l}\text { Edukasi } \\
\text { mengenai } \\
\text { biota laut }\end{array}$ & $\begin{array}{l}\text { Bioskop 3D } \\
\text { dan aquarium }\end{array}$ \\
\hline & $\begin{array}{l}\text { Kegiatan } \\
\text { bermain anak }\end{array}$ & $\begin{array}{l}\text { Eco children } \\
\text { park, kincir } \\
\text { angin raksasa, } \\
\text { komedi putar, } \\
\text { labirin dan } \\
\text { taman terbuka } \\
\text { hijau. }\end{array}$ \\
\hline & $\begin{array}{l}\text { Kegiatan } \\
\text { wisata pantai }\end{array}$ & dermaga \\
\hline & Berbelanja & Toko souvenir \\
\hline & $\begin{array}{l}\text { Makan dan } \\
\text { minum }\end{array}$ & Food court \\
\hline & Pergi & Pintu keluar \\
\hline \multirow[t]{3}{*}{ Pengelola } & Datang & Entrance \\
\hline & Parkir & $\begin{array}{l}\text { Parkir } \\
\text { pengelola }\end{array}$ \\
\hline & Bekerja & $\begin{array}{l}\text { Kantor } \\
\text { pengelola }\end{array}$ \\
\hline
\end{tabular}

\begin{tabular}{|l|l|l|}
\hline \multirow{4}{*}{} & Ibadah & Mushola \\
\cline { 2 - 3 } & Metabolisme & $\begin{array}{l}\text { Toilet } \\
\text { pengelola }\end{array}$ \\
\cline { 2 - 3 } & $\begin{array}{l}\text { Menemui } \\
\text { tamu }\end{array}$ & Ruang tamu \\
\cline { 2 - 3 } & Pergi & Entrance \\
\hline
\end{tabular}

Pada Tabel 1. terlihat kebutuhan peruangan yang dibutuhkan dalam pemenuhan wadah taman rekreasi.

\subsection{Analisis Lokasi}

Selain menentukan lokasi yang strategis, memilih tapak dengan kondisi yang mendukung kegiatan taman rekreasi.

1. Tujuan : Tapak sebagai lokasi Taman Rekreasi Pantai Pasarbanggi.

2. Dasar pertimbangan: Luasan tapak memenuhi kegiatan ruang untuk taman rekreasi, kemudahan dalam hal pencapaian, tapak strategis.

3. Proses Analisis : Tapak terpilih berada pada Jalan Jenderal Sudirman, Kelurahan Pasarbanggi, Kabupaten Rembang dengan luas $\pm 4,5 \mathrm{Ha}$.

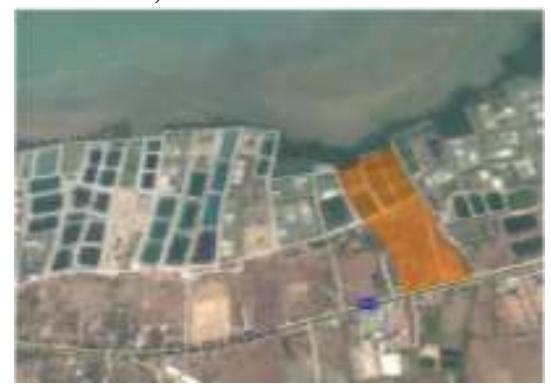

Gambar 1. Pemilihan Tapak

Pada Gambar 1 terlihat area berwarna jingga yang merupakan area tapak terpilih.

\subsection{Analisis Pencapaian}

Pencapaian ke dalam bangunan harus mudah diakses, mudah dilihat dan memiliki sirkulasi yang aman akan menstimulus orang untuk masuk dalam area bangunan.

1. Tujuan: Main entrance dan side entrance pada tapak sesuai dengan kondisi lingkungan sekitar.

2. Dasar Pertimbangan: Kemudahan akses, tidak menimbulkan gangguan lalu lintas, kemudahan visual pengunjung.

3. Proses analisis 


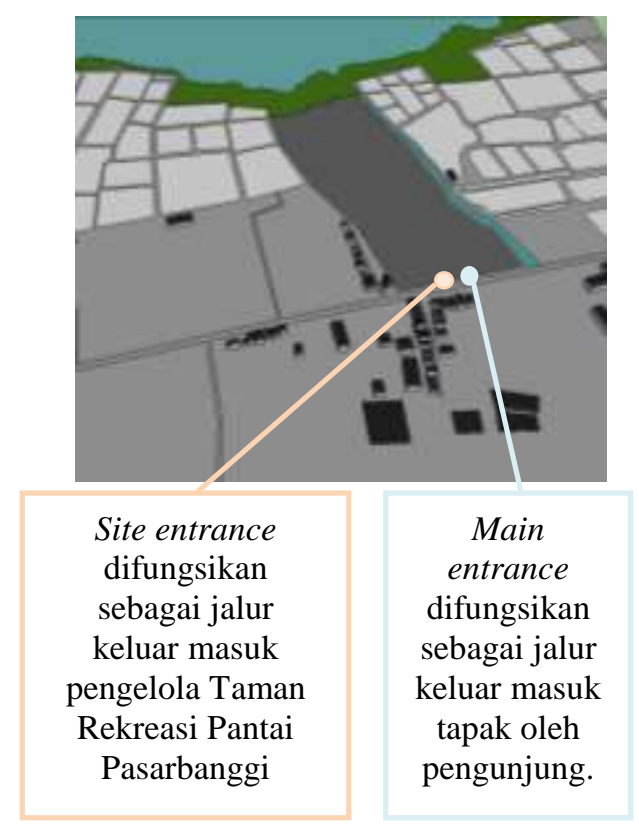

Gambar 2. Pola Pencapaian

Pada Gambar 2 terlihat pola pencapaian pada tapak berdasarkan pengguna.

\subsection{Analisis Pemintakatan (Penzoningan)}

Pemintakatan berdasarkan sifat kegiatan dan keadaan dalam tapak dilakukan sebagai acuan dalam penataan peruangan, namun tetap memperhatikan modul-modul struktur yang telah diterapkan.

1. Tujuan: Mintakat (zoning) pada Taman Rekreasi Pantai Pasarbanggi.

2. Dasar pertimbangan: Kemudahan akses, keamanan dan kenyamanan, berdasarkan analisis-analisis yang telah dilakukan sebelumnya.

3. Proses analisis: Persyaratan ruang, berdasarkan kelompok kegiatan, kesesuaian lokasi tapak dan analisis pengolahan tapak.

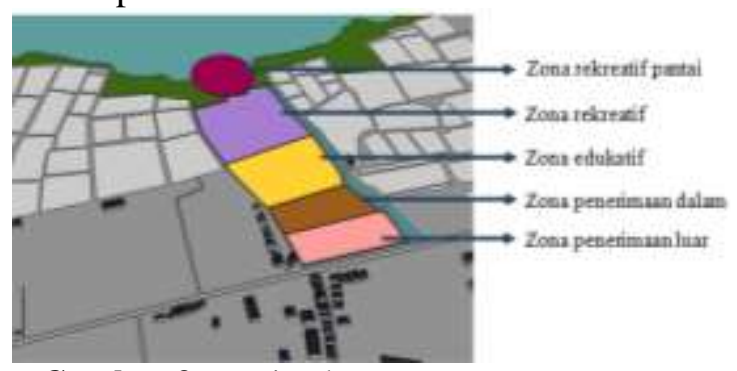

Gambar 3. Pemintakatan

Pada Gambar 3 terlihat pemintakatan pada tapak, dibedakan menjadi lima bagian.

\section{Analisis Bentuk dan Tampilan Bangunan}

Bentuk massa bangunan didapatkan dari pengolahan dasar bergelombang dengan pola tata massa jamak.

1. Tujuan : Bentuk dasar bangunan Taman Rekreasi Pantai Pasarbanggi.

2. Dasar Pertimbangan : Bentuk atraktif, sesuai dengan iklim tropis tapak.

3. Proses analisis : Bentuk dasar atap lengkung bergelombang.

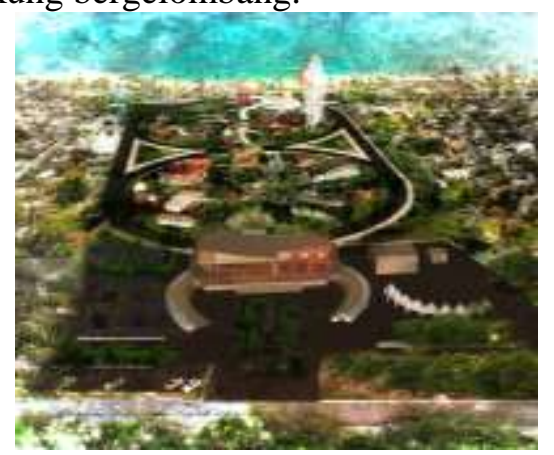

Gambar 4. Bentuk Bangunan

Pada Gambar 4 terlihat bentuk bangunan pada tapak yang memiliki bentuk atap lengkung.

\section{Analisis Material Bangunan}

Pemilihan material yang digunakan dapat mengurangi dampak kerusakan lingkungan.

1. Tujuan : Pemilihan material dan finishing bangunan.

2. Dasar Pertimbangan : Material aman digunakan baik selama proses konstruksi maupun pasca konstruksi, tahan lama, sesuai dengan kondisi iklim tropis tapak.

3. Proses Analisis : Pemilihan material menekankan pada efisiensi penggunaan dan energi, kualitas dan daya tahan material.

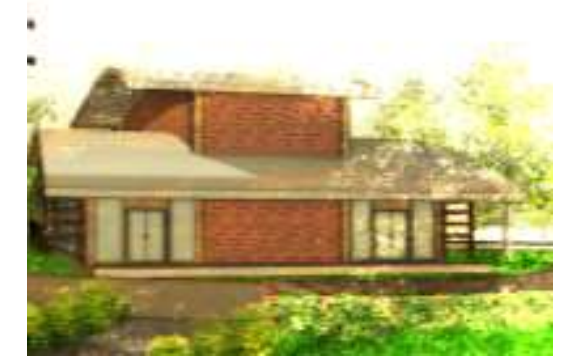

Gambar 5. Material Eksterior 


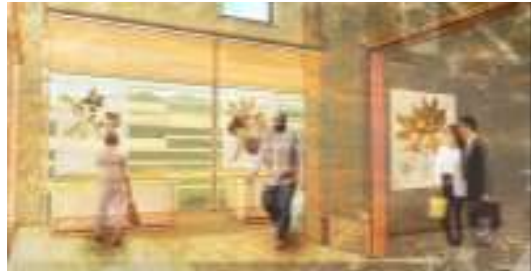

Gambar 6. Material Interior

Pada Gambar 5 dan 6 terlihat penggunaan material lokal dan efisiensi material seperti batu bata ekspos, plafond kayu bekas peti kemas, kaca transparan sebagai material bukaan dan lantai beton ekspos sebagai material interior maupun eksterior.

\subsection{Analisa Sistem Utilitas}

\subsubsection{Utilitas Listrik}

1. Tujuan : Sistem jaringan listrik untuk menunjang kegiatan pengguna.

2. Dasar Pertimbangan : Tidak mengganggu keselamatan dan kesehatan pengguna, tidak mengganggu visual, minimalisasi energi yang dikeluarkan.

3. Proses Analisis : Jaringan listrik berasal dari listrik PLN, genset sebagai energi cadangan dan panel surya sebagai energi alternatif.

\subsubsection{Utilitas Air Bersih}

1. Tujuan : Sistem air bersih yang digunakan untuk kebutuhan taman rekreasi.

2. Dasar Pertimbangan : Sumber air berasal dari tapak atau daerah sekitar tapak, penggunaan air tidak merusak lingkungan.

3. Proses Analisis : Air bersih berasal dari air sumur, PDAM, dan air hujan yang ditampung. Sumur ditempatkan pada zona yang jauh dari pantai untuk mengurangi kadar salinitas pada air bersih yang digunakan.

\subsubsection{Analisis Utilitas Air Kotor}

1. Tujuan : Sistem jaringan air kotor berupa air limbah.

2. Dasar Pertimbangan : Pembuangan air limbah tidak mengganggu kesehatan, penciuman, visual maupun kenyamanan pengguna, menjaga kadar air tanah.

3. Proses Analisis : Air limbah dari toilet sebelumnya didistribusikan melalui bak kontrol, kemudian masuk ke sumur resapan. Air sisa wudhu didistribusikan melalui saluran drainase untuk menyiram tanaman.

\subsection{Analisis Lansekap}

\subsubsection{Analisis sirkulasi}

1. Tujuan : Sistem sirkulasi pada bangunan dan taman rekreasi.

2. Dasar Pertimbangan : Memudahkan pengguna untuk mencapai suatu tempat, terdiri dari sirkulasi bagi manusia dan kendaraan, sirkulasi dapat digunakan untuk difabel.

3. Proses Analisis : Sirkulasi luar kawasan terdiri dari sirkulasi untuk pengunjung dan pengelola, dengan moda transportasi berupa mobil, motor, bis dan pejalan kaki.

Sirkulasi dalam kawasan terdiri dari sirkulasi horisontal yaitu pintu masuk utama menuju kawasan wisata dan pintu masuk bangunan; pencapaian bangunan dengan menggunakan pencapaian langsung; jalur penghubung antar zona dengan pola lengkung; pola linier untuk sirkulasi zona servis; jalur bagi pengguna sepeda; dan dermaga.

Sirkulasi Vertikal terdiri dari ramp dan tangga.

\subsubsection{Analisis Elemen Pembentuk}

\section{Lansekap.}

\section{Soft Material}

1. Tujuan : Elemen pembentuk lansekap berupa soft material.

2. Dasar Pertimbangan : Soft material berupa vegetasi disesuaikan dengan kondisi tapak, mendukung fungsi, kenyamanan dan estetika.

3. Proses Analisis

Soft material yang dimaksud adalah tanaman dan air. Pemilihan vegetasi berupa vegetasi yang berfungsi sebagai peneduh yaitu flamboyan dan angsana; vegetasi sebagai penunjuk arah yaitu palem raja; vegetasi penghasil buahbuahan yaitu sawo jamblang, sawo kecil dan sawo manila; vegetasi penghias yaitu pohon soka, tagetes, lantana, dan kana; vegetasi pengikat massa yaitu azela bulat, pucuk merah, dan teh-tehan; vegetasi penyaring udara yaitu lidah mertua, palem kuning dan lili paris; vegetasi ground cover yaitu rumput gajah dan rumput jepang. 
Air mancur dan kolam buatan sebagai soft material yang mendukung estetika.

\section{Hard Material}

1. Tujuan : Elemen pembentuk lansekap berupa hard material.

2. Dasar Pertimbangan : Mendukung fungsi, kenyamanan, dan estetika, dan mendukung konsep ekologis.

3. Proses Analisis

Hard material terdiri dari tempat tempat sampah dengan material ramah lingkungan yang ditempatkan pada beberapa titik kawasan, papan petunjuk arah pada luar kawasan maupun dalam kawasan, bangku taman, gazebo, material perkerasan berupa grass block, dan pergola.

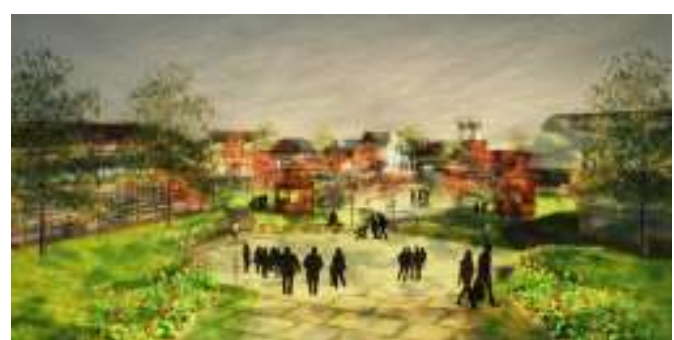

Gambar 7. Perspektif Zona Edukatif

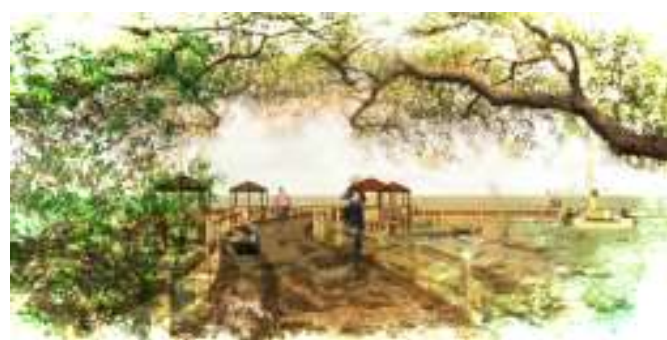

Gambar 8. Perspektif Zona Rekreatif Pantai

Pada Gambar 7 dan 8 terlihat pengaplikasian soft material dan hard material berupa tanaman, perkerasan jalan, dan gazebo.

\section{KESIMPULAN (KONSEP DESAIN)}

Konsep rancangan Taman Rekreasi Pantai Pasarbanggi mengacu pada konsep Arsitektur Ekologis yang lebih fokus pada pengolahan tapak dan pantai pada kawasan dengan menggunakan material lokal dan efisien pada bangunan. Bangunan ini dirancang untuk mewadahi kegiatan rekreasi pantai, bermain anak, dan kegiatan edukatif.
Pengolahan tapak, penggunaan material dan manajemen limbah dilakukan dengan mempertimbangkan aspek Arsitektur Ekologis, estetika dan kenyamanan pengguna.

Hasil analisis dan hasil korelasi dari beberapa data di atas, diperoleh hasil berupa rancangan Taman Rekreasi Pantai Pasarbanggi, Kabupeten Rembang sebagai berikut.

Nama Bangunan : Taman Rekreasi Pantai Pasarbanggi

Luas Lahan $\quad: 45.000 \mathrm{~m}^{2}$

Luas Bangunan : $18.000 \mathrm{~m}^{2}$

Daya Tampung : 2.000 orang

Kegiatan : Wisata Rekreatif Pantai, wisata bermain, wisata edukasi.

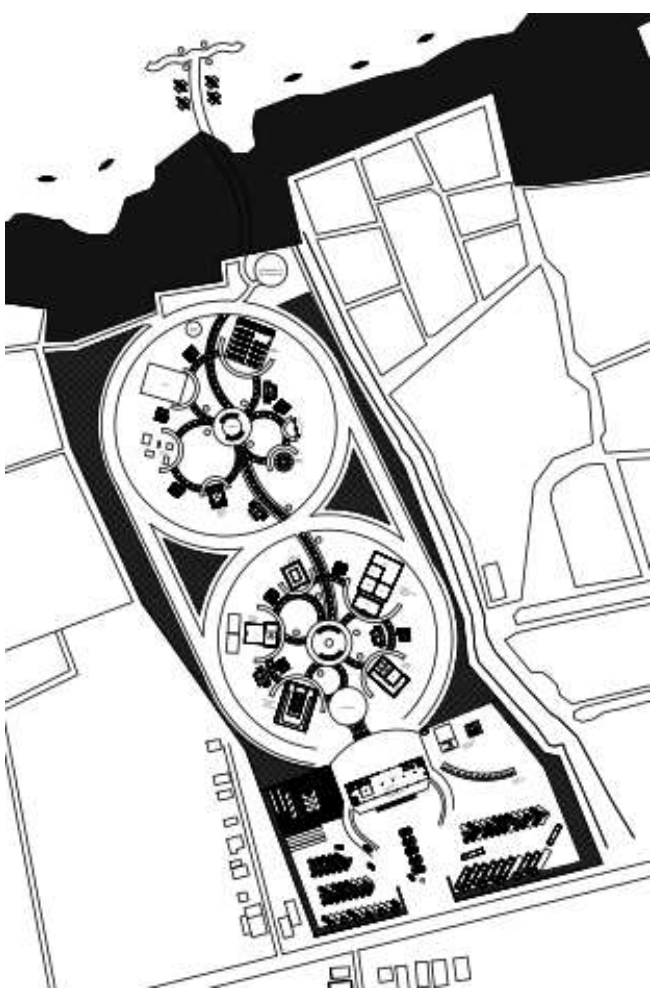

Gambar 9. Rencana Tapak

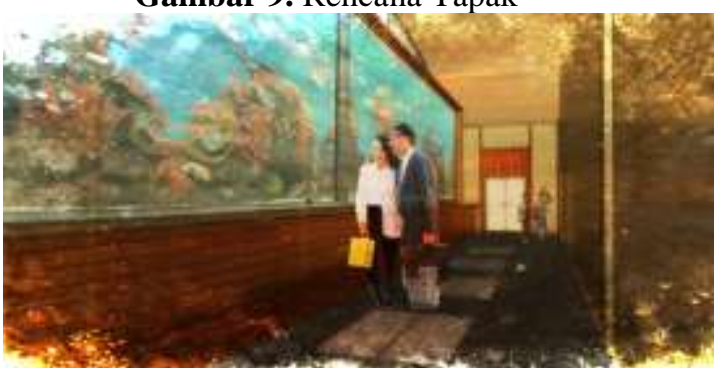

Gambar 10. Interior Bangunan Bioskop 3D dan Aquarium 
Pada Gambar 9 terlihat bentuk pengolahan dan penataan tapak, pada gambar 10 terlihat efisiensi penggunaan material yaitu dinding batu bata ekspos dan beton ekspos untuk lantai.

\section{REFERENSI}

A Yoeti, Oka. Pengantar Ilmu Pariwisata. Bandung: Angkasa, 1996.

Dinas Kebudayaan Pariwisata Pemuda dan Olah Raga Kabupaten Rembang (2014) . Rembang dalam Angka Tahun 2014.

(http://www.rembangkab.go.id/index.p hp/publikasi/rembang-dalam-angka, diakses 8 April 2015.)

Dinas Kelautan dan Perikanan Kabupaten Rembang. Profil KP 2013.

(http://www.rembangkab.go.id/, diakses 26 Maret 2015.)

Frick, Heinz. Dasar-dasar eko-arsitektur. Konsep arsitektur berwawasan lingkungan serta kualitas konstruksi dan bahan bangunan untuk rumah sehat dan dampaknya atas kesehatan manusia. Yogyakarta: Kanisius, 1998.

Rencana Kerja Pemerintah Daerah (RKPD) Kabupaten Rembang tahun 2015, (www.rembangkab.go.id, diakses tanggal 26 Maret 2016.) 